Berlin Working Papers on Money, Finance, Trade and Development

Working Paper No. 02/2011

The Impact of China-EU Trade on Climate Change

Yan Yunfeng

Yang Laike

June 2011

In cooperation with

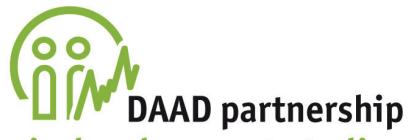

Center

\author{
Jan Priewe
}




\title{
The Impact of China-EU Trade on Climate Change
}

\author{
Yan Yunfeng*, Yang Laike**, Jan Priewe *** \\ * School of Business, East China Normal University, Shanghai, China \\ ** School of Finance and Statistics, East China Normal University, Shanghai, China \\ *** HTW Berlin - University of Applied Science, Berlin, Germany
}

\begin{abstract}
International trade has a significant impact on greenhouse gas (GHG) emissions and global climate change. In this respect, trade between China and the European Union, as the world's two biggest exporters, is critical to the global GHG emission reduction efforts. The EU-15 is committed to reducing its $\mathrm{CO}_{2}$ emissions under the Kyoto Protocol. However, if the EU reaches its pledged targets by importing $\mathrm{CO}_{2}$ intensive products from China, thereby effectively outsourcing its own emissions to an extent of ca $13.6 \%$ of EU's total energy-related $\mathrm{CO}_{2}$ emissions (2006/7); this hollows out and counters the spirit of the EU's reduction commitment. The paper analyzes $\mathrm{CO}_{2}$ emissions embodied in China-EU trade from 1995-2006. $\mathrm{CO}_{2}$ emissions embodied in China's exports to the EU and in the EU's exports to China were highly imbalanced. The $\mathrm{CO}_{2}$ emissions embodied in China's exports to the EU were $95.04 \mathrm{Mt}$ in 1995 and $532.35 \mathrm{Mt}$ in 2006, accounting for $2.99 \%$ and $8.85 \%$ of China's $\mathrm{CO}_{2}$ emissions respectively. On the other hand, those of the EU's exports to China were only 5.78 Mt in 1995 and $26.05 \mathrm{Mt}$ in 2006 , accounting for only $0.17 \%$ and $0.73 \%$ of the EU's emissions respectively. The paper also shows that the scale effect caused the increase of emissions embodied in China's exports to the EU, while the technology effect and the composition effect offset some of the increases. In terms of sectoral composition, the exports from China to the EU in "fabricated metal products, machinery and equipment", "basic metals and other non-metallic mineral products", "rubber, plastics products, and other manufacturing" and "chemicals and chemical products" accounted for a substantial proportion of China's trade-embodied emissions. The paper concludes that the present trend is unsustainable and leads to ever-increasing trade distortions with environmentally counter-productive incentives. Policy responses are needed, first and foremost a continual carbon footprint accounting system between the EU and China. Finally three policy options to gradually lower imbalances and distortions are outlined.
\end{abstract}

Keywords: China-EU Trade, Climate Change, Input-output approach (IOA)

\section{Introduction}

The past ten years have been marked by an unprecedented expansion of the trade between China and the European Union (EU). Trade in goods between the two reached EUR 326 billion in 2008, which was 4.5 times larger than in 1999; thus, the China-EU trade relationship has grown into one of the largest and most important in the world. In 2008, the China-EU trade deficit in commodities reached EUR 169.2 billion. This imbalance has triggered several trade disputes, but relatively little attention has been paid to its environmental impacts.

International trade has serious environmental impacts. Trade results in a geographic separation of consumers and the pollution associated with the consumption of goods, which creates a mechanism for consumers to shift this pollution to other countries. This could substantially complicate efforts aimed at addressing the problems of climate change by merely shifting, for example, emission of greenhouse gases (GHGs) to other countries. The Kyoto Protocol set 
legally binding commitments for industrialized countries to reduce their overall emissions of six GHGs by 5.2\% below the 1990 level during the years 2008-2012. The EU has ratified the Kyoto Protocol and committed to reducing its GHG-emission by at least $20 \%$ by 2020 compared to 1990 levels. However, if the EU reaches its emissions targets by importing $\mathrm{CO}_{2}$-intensive products from China or other developing countries, achieving this goal will be less meaningful in global terms.

In this study, we analyze the impact of China-EU trade on climate change, focusing on $\mathrm{CO}_{2}$ emissions embodied in international trade. "Carbon leakage" in China-EU trade could be a noteworthy feature, given the carbon-intensive industries in China and the growing volume of trade between China and the EU, likely adding to future disputes between the two parties for years to come. Besides, $\mathrm{CO}_{2}$ is by far the largest $\mathrm{GHG}$ by volume, representing about $71.4 \%$ of the total emissions of the six gases (WRI, 2010).

Several previous studies have established theoretical models to analyze the environmental effects of trade. Copeland \& Taylor (1994, 1995) and Chichilnisky (1994) developed the North-South trade model to examine linkages between pollution and international trade. They argued that free trade deteriorates the environment. It was Grossman and Krueger (1991) who developed a conceptual framework to examine how trade may actually affect the environment. This framework breaks down the environmental impact of the North American Free Trade Agreement (NAFTA) into three "effects": the scale effect, the composition effect and the technology effect. More and more studies use this analytic framework to investigate the link between trade and climate change. For example, Antweiller et al. (2001) estimate the scale, composition and technology effects of $\mathrm{SO}_{2}$ emissions using a general equilibrium model of trade and environment. Peters et al. (2007) and Guan et al. (2008) analyze the drivers of China's growing $\mathrm{CO}_{2}$ Emissions using the same framework.

Due to rapidly expanding foreign trade and the continuing deterioration of its environmental conditions, China has attracted many studies in recent years, and a number of these have found a positive correlation between trade and $\mathrm{CO}_{2}$ emission.

Shui and Harriss (2006) estimated that about 7\% in 1997 and $14 \%$ in 2003 of China's $\mathrm{CO}_{2}$ emissions are the results of producing goods for export to the USA.

$\mathrm{Li}$ and Hewitt (2008) found that China-UK trade resulted in an additional $117 \mathrm{Mt}$ of $\mathrm{CO}_{2}$ to global $\mathrm{CO}_{2}$ emissions in 2004. Wang \& Watson (2008) concluded that net exports from China accounted for $23 \%$ of its total $\mathrm{CO}_{2}$ emissions in 2004. Similarly, Weber et al. (2008) found that in 2005, around one-third of Chinese $\mathrm{CO}_{2}$ emissions were generated by the production of goods 
for export; this proportion has risen from only $12 \%$ in 1987 and up from only $21 \%$ as recently as 2002. Yan \& Yang (2010) also argued that $10.03 \%$ in 1997 and $26.54 \%$ in 2007 of China's annual $\mathrm{CO}_{2}$ emissions are produced during the manufacture of its exports. On the other hand, focusing on the EU, Kornerup et al. (2008) found that global $\mathrm{CO}_{2}$ emissions caused by total consumption in the EU were $12 \%$ higher than the total $\mathrm{CO}_{2}$ emissions that occurred within the EU in 2001.

While the studies mentioned here provide useful insights into China-EU bilateral trade, none has examined China-EU trade and $\mathrm{CO}_{2}$ emissions. However, a growing awareness of the problems posed by climate change has drawn attention to the environmental implications of trade in recent years. Using Input-Output approach, this paper not only estimates the quantity of $\mathrm{CO}_{2}$ embodied in China-EU trade, but also decomposes the emission changes into three effects: the scale effect, technology effect and composition effect. Moreover, the paper identifies the sectors contributing most to these embodied $\mathrm{CO}_{2}$ emissions.

\section{China-EU trade and the $\mathrm{CO}_{2}$ Emissions}

China's accession to the WTO in 2001 resulted in a surge in trade between it and the EU. Since then, the trade imbalance between the two has quickly widened, resulting in several trade frictions between them (see Figure 1).

Figure 1: Trade balance of EU-27 with China

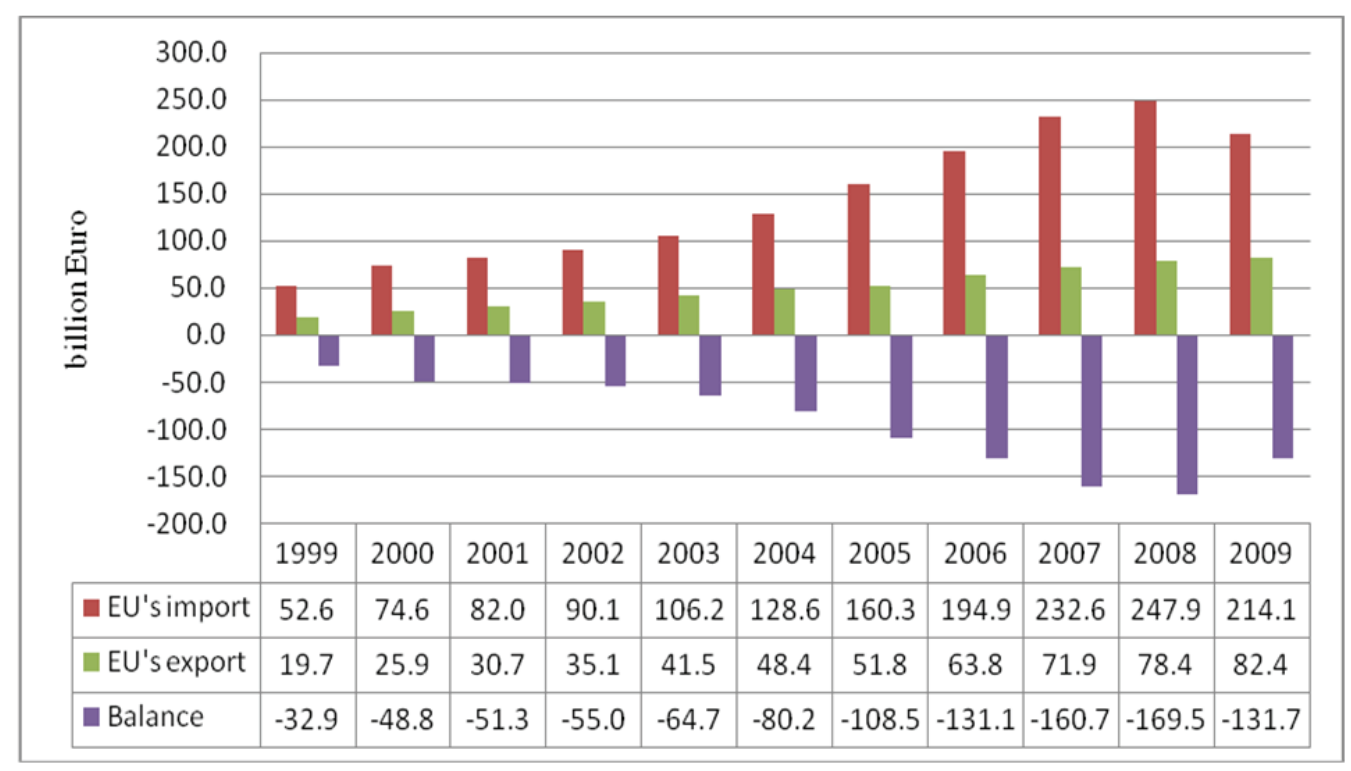

Source: Eurostat (2011)

Apart from trade itself, global climate change has become one of the most serious international 
issues. Having already increased from 20.9 gigatonnes (Gt) in 1990 to 28.8 Gt in 2007, global $\mathrm{CO}_{2}$ emissions are projected to reach $34.5 \mathrm{Gt}$ in 2020 and $40.2 \mathrm{Gt}$ in 2030 in a reference scenario ${ }^{1}$. Both China and EU are major contributors to $\mathrm{CO}_{2}$ emissions. There is, however, a significant difference between the two parties' $\mathrm{CO}_{2}$ emissions trends. China's $\mathrm{CO}_{2}$ emissions increased sharply over the past decade, but especially in recent years. It overtook the EU in 2004 and overtook the US in 2006, becoming the world's highest-emitting economy. Between 2000 and 2007, China's total energy-related $\mathrm{CO}_{2}$ emissions doubled to be $6.1 \mathrm{Gt}$ in 2007. Nevertheless, the EU energy-related $\mathrm{CO}_{2}$ emissions decreased from 4.1 Gt in 2000 to $3.9 \mathrm{Gt}$ in 2007 . Given its rapid economic development, China's emissions have grown very quickly over recent decades. This is a trend that is expected to continue. According to the International Energy Agency (IEA) estimation, China's emissions will continue to increase rapidly, reaching $11.6 \mathrm{Gt}$ in 2030 - this is an increase of over $90 \%$ over the given period. By 2030, China will account for $29 \%$ of the world's emissions. The EU's $\mathrm{CO}_{2}$ emissions, on the other hand, are expected to fall from 3.9 Gt in 2007 to $3.5 \mathrm{Gt}$ in 2030 in the Reference Scenario (see Figure 2) (IEA, 2009).

Figure 2: Annual energy-related $\mathrm{CO}_{2}$ emissions in the reference scenario

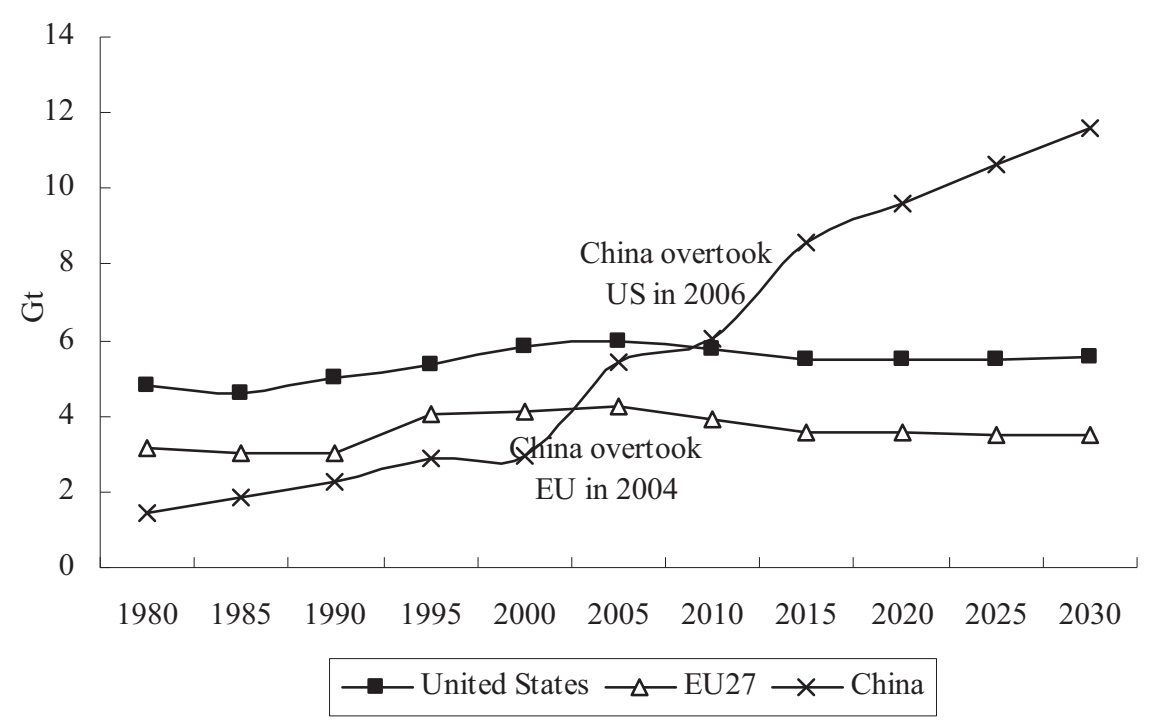

Source: IEA, 2009, World Energy Outlook

When comparing their potential contributions to climate change, it is important to consider China and the EU's historical contributions to global emissions and per capita emissions. China currently accounts for $20 \%$ of the world's annual $\mathrm{CO}_{2}$ emissions. However, its contribution to

\footnotetext{
${ }^{1}$ A reference scenario published by IEA provides a baseline picture of how global energy markets would evolve if governments make no changes to their existing policies and measures (WEO, 2009).
} 
the stock of emitted $\mathrm{CO}_{2}$ as a whole is notably smaller when the time period under consideration is extended back to the beginning of the 1990s. In this case, China accounted for only $8.92 \%$ of the world's cumulative emissions. The EU-27 accounts for $25.07 \%$ of the world's historical emissions on this basis (see Table 1). In terms of cumulative emissions per capita, the gap between China and the EU is wide. China's cumulative per capita emissions from 1990 to 2005 is $76 \mathrm{MtCO}_{2}$ at the rank of 88 , while the EU's per capita emissions are almost 8 times greater that of China's.

Table 1: Cumulative energy-related $\mathrm{CO}_{2}$ Emissions (1900-2006)

\begin{tabular}{lrrrrrr}
\hline Country & \multicolumn{1}{l}{$\mathrm{Mt} \mathrm{CO}_{2}$} & Rank & $\%$ of World Total & $\begin{array}{l}\mathrm{Mt} \mathrm{CO}_{2} \\
\text { Person }\end{array}$ & Per & Rank \\
& & & & $29.12 \%$ & $1,092.4$ & $(2)$ \\
United States of America & $323,916.3$ & $(1)$ & $25.07 \%$ & 569.0 & $(16)$ \\
European Union (27) & $278,828.1$ & $(2)$ & $8.92 \%$ & 76.0 & $(88)$ \\
China & $99,204.1$ & $(3)$ & $8.33 \%$ & 647.2 & $(11)$ \\
Russian Federation & $92,647.5$ & $(4)$ & $6.70 \%$ & 904.0 & $(6)$ \\
Germany & $74,552.5$ & $(5)$ & $4.99 \%$ & 921.4 & $(4)$ \\
United Kingdom & $55,492.8$ & $(6)$ & $4.00 \%$ & 348.5 & $(36)$ \\
Japan & $44,535.2$ & $(7)$ & $2.61 \%$ & 476.7 & $(24)$ \\
France & $29,018.2$ & $(8)$ & $2.46 \%$ & 25.0 & $(123)$ \\
India & $27,321.0$ & $(9)$ & $2.25 \%$ & 530.7 & $(21)$ \\
Ukraine & $24,998.0$ & $(10)$ & & & \\
\hline
\end{tabular}

Source: World Resources Institute, Climate Analysis Indicators Tool (CAIT) Version 7.0. Washington, DC:, 2010.

\section{Methodology: the input-output framework and Structural Decomposi- tion Analysis (SDA)}

The input-output analysis (IOA) was first applied in 1972 by Leontef to describe economic-environmental relationships. It recent years it has been widely used to assess the impact of trade on global $\mathrm{CO}_{2}$ emissions. Using input-output analysis (IOA), the total output of an economy is expressed as:

$$
X=(I-A)^{-1} Y \quad(1)
$$

In the above expression, $X$ is the vector of output, and $I$ is the identity matrix, which is a diagonal matrix with the diagonal elements one and others zero. The term $A$ is a matrix of direct requirements, and $(I-A)^{-1}$ is Leontief inverse, which represents total requirements matrix (direct plus indirect). $Y$ is the vector of final demand. 
Appropriate extensions of the input-output system allow us to evaluate the direct and indirect impacts of economic policies on other economic variables such as labor, capital, energy and emissions. Most of these policy issues have to be analyzed with macroeconomic models that provide a minimum of sectoral disaggregation. So, $\mathrm{CO}_{2}$ emissions embodied in international trade can be assessed by multiplying the $\mathrm{CO}_{2}$ emissions factor using foreign trade figures (export and import vectors).

If $E$ is direct $\mathrm{CO}_{2}$ emission factors, the total emissions $F$ generated by the final demand $Y$ are given by:

$$
F=E(I-A)^{-1} Y
$$

Then, the $\mathrm{CO}_{2}$ emission embodied in exports can be acquired by multiplying the $\mathrm{CO}_{2}$ emissions factor by export and vector $Y^{e x}$

$$
F=E(I-A)^{-1} Y^{e x}
$$

However, a portion of China's and the EU's exports are imported from other countries before they are reprocessed for final export. Therefore, we distinguish between domestically produced and imported products. $A$ is broken into two components representing the inter-industry requirements of domestically produced products and the inter-industry requirements of imported products, $A=A^{d}+A^{i m}$ (United Nations, 1999). The equation (2) is written as:

$$
F=E\left(I-A^{d}\right)^{-1} Y^{e x}
$$

With $A^{d}=A-A^{i m}$, it is important to note that the requirement matrix should be $A^{d}$ and not $A$. $A$ represents the technology used in the total economy, while $A^{d}$ represents the amount of domestic inputs used. $A^{i m}$ is obtained by: $A^{i m}=M^{*} A$, where $M$ is import coefficient, which is the share of imports in the supply of products to each sector. $M$ is a diagonal matrix with components $m_{i i}$.

$$
m_{i i}=\frac{i m_{i}}{x_{i}+i m_{i}-e x_{i}}(i=1,2, \ldots \ldots, \text { n }) ; \text { if } i \neq j, m_{i i}=0
$$

So, the emissions embodied in exports can be shown to be equal to:

$$
F=E[I-(I-M) A]^{-1} Y^{e x}
$$

To know the major source contributing to increasing $\mathrm{CO}_{2}$ emissions, we can decompose the trade-induced $\mathrm{CO}_{2}$ emissions by scale, composition and technology effects. To do this, we 
further decompose $Y^{e x}$ into $Y^{e x}=\left[Y^{e x} /\left(i^{\prime} Y^{e x}\right)\right]\left(i^{\prime} Y^{e x}\right)$, where $i=(1,1, \ldots 1)^{\mathrm{T}}$. When $Y_{s}^{e x}=\left[Y^{e x} /\left(i^{\prime} Y^{e x}\right)\right], Y_{v}^{e x}=i^{\prime} Y^{e x}$ and $L=[I-(I-M) A]^{-1}$, Eq. (5) can be summarized as follows:

$$
F=E L Y_{s}^{e x} Y_{v}^{e x}
$$

A structural decomposition of the change of $\mathrm{CO}_{2}$ emissions embodied in trade between two periods (0) and (1) can be derived as follows:

$$
\Delta F=F(1)-F(0)=E(1) L(1) Y_{s}^{e x}(1) Y_{s}^{e x}(1)-E(0) L(0) Y_{s}^{e x}(0) Y_{s}^{e x}(0)
$$

When conducting a structural decomposition analysis SDA), it is possible to compare terms relative to the start or end of each time-period. However, this does lead to a non-uniqueness problem (Dietzenbacher, 1998). A common solution to this problem is to use the average of the two polar decomposition forms.

If it is decomposed from period (0), Eq. (7) is written as:

$$
\Delta F=\Delta E L(0) y_{s}^{e x}(0) y_{s}^{e x}(0)+E(1) \Delta L y_{s}^{e x}(0) y_{s}^{e x}(0)+E(1) L(1) \Delta y_{s}^{e x} y_{s}^{e x}(0)+E(1) L(1) y_{s}^{e x}(1) \Delta y_{s}^{e x}(8)
$$

If it is decomposed from period (1), Eq. (7) can be written as:

$$
\Delta F=\Delta E L(1) y_{s}^{e x}(1) y_{s}^{e x}(1)+E(0) \Delta L y_{s}^{e x}(1) y_{s}^{e x}(1)+E(0) L(0) \Delta y_{s}^{e x} y_{s}^{e x}(1)+E(0) L(0) y_{s}^{e x}(0) \Delta y_{s}^{e x}(9)
$$

Then, the total changes of $\mathrm{CO}_{2}$ emissions embodied in trade $\Delta F$ can be calculated as the average of Eq. (8) and Eq. (9)

$$
\begin{aligned}
& \Delta F=\frac{1}{2}\left[\Delta E L(0) Y_{s}^{e x}(0) Y_{s}^{e x}(0)+\Delta E L(1) Y_{s}^{e x}(1) Y_{s}^{e x}(1)\right]+\frac{1}{2}\left[E(1) \Delta L Y_{s}^{e x}(0) Y_{s}^{e x}(0)+E(0) \Delta L Y_{s}^{e x}(1) Y_{s}^{e x}(1)\right] \\
& +\frac{1}{2}\left[E(1) L(1) \Delta Y_{s}^{e x} Y_{s}^{e x}(0)+E(0) L(0) \Delta Y_{s}^{e x} Y_{s}^{e x}(1)\right]+\frac{1}{2}\left[E(1) L(1) Y_{s}^{e x}(1) \Delta Y_{s}^{e x}+E(0) L(0) Y_{s}^{e x}(0) \Delta Y_{s}^{e x}\right]
\end{aligned}
$$

Eq. (10) can be written simply as below:

$$
\Delta F=f(\Delta E)+f(\Delta L)+f\left(\Delta Y_{s}^{e x}\right)+f\left(\Delta Y_{s}^{e x}\right)
$$

The first and second terms are the changes of embodied $\mathrm{CO}_{2}$ emission factors (direct and indirect factors). With improvements in carbon efficiency and production technology, emissions produced during the whole production process decline. We call this the "technology effect". The third term is the "composition effect", which represents changes in the trade structure. The composition effect refers to each sector's share in a country's total trade, resulting in the expansion of some sectors and the contraction of others. The resulting increase or decrease of $\mathrm{CO}_{2}$ emissions will depend on whether the emission-intensive sectors are expanding or contracting. Changes in the structure of a liberalizing country's production will depend on where the 
country's "comparative advantage" lies. If its comparative advantage is in sectors that are less emission-intensive, then opening trade will lead to lower emissions. If the comparative advantage is in the more emission-intensive sectors, however, then liberalization will lead to greater emissions. The fourth term is the "scale effect", which represents the change in emissions resulting from a change in the trade volume.

\section{Data source and adjustment}

Most of the data used in the study have been gathered from the estimates from the OECD's international harmonized database. The sector classification of OECD input-output table, bilateral trade database (BTD), and the IEA $\mathrm{CO}_{2}$ emissions from fuel combustion are formatted and harmonized following the sector classification of "International Standard Industrial Classification of All Economic Activities" (ISIC Revision 3). Due to the limitations of detailed emission factors by sector, 15 aggregated sectors (see Table 2) are used in this study. Further, the empirical analysis of EU is limited to the EU-15 due to their economic weight in EU, as well as a lack of data for many of the other EU countries.

\section{Table 2: Sector Classification}

\begin{tabular}{ll}
\hline Sector & ISIC Rev. 3 \\
\hline 1 Agriculture, hunting, forestry and fishing & $1+2+5$ \\
2 Mining, quarrying and petroleum refining & $10-14,23$ \\
3 Food products, beverages and tobacco & $15+16$ \\
4 Textiles, textile products, leather and footwear & $17+18+19$ \\
5 Wood and products of wood and cork & 20 \\
6 Pulp, paper, paper products, printing and publishing & $21+22$ \\
7 Chemicals and chemical products & 24 \\
8 Basic metals and other non-metallic mineral products & $26+27$ \\
9 Fabricated metal products, machinery \& equipment & $28-32$ \\
10 Transport equipment & $34+35$ \\
11 Rubber and plastics products and other manufacturing & $25,33,36,37$ \\
12 Utilities & $40+41$ \\
13 Construction & 45 \\
14 Transport and storage & $60-63$ \\
15 All other services & $50-55,64-99$ \\
\hline
\end{tabular}

Source: Nakano et al., 2009. 
Input-output tables: Included in the latest version of the OECD Input-Output database (2009 Edition) are input-output tables for China and EU-15 for the years 1995, 2000, and 2005. For the missing years, we filled the table with data from the closest years with the most available data. In so doing, we assume that production technologies and relative prices (hence IO coefficients) remain constant for short periods of time (Ahamad \& Wyckoff, 2003).

Trade data: To link with the input-output tables, the latest OECD structural analysis bilateral trade database (STAN BTD) is used, which is based on ISIC Rev.3 and similar to the OECD Input-Output database. Trade refers to that which occurs between EU-15 and mainland China. $\mathrm{CO}_{2}$ emission factors: The $\mathrm{CO}_{2}$ emission factor is the average unit of $\mathrm{CO}_{2}$ emitted per unit of sectoral output. As the data are not directly available, it is constructed from IEA's $\mathrm{CO}_{2}$ Emissions from Fuel Combustion data, which is also based on ISIC Rev.3. Direct $\mathrm{CO}_{2}$ emission factor by sector for each country is simply calculated through dividing emissions to sector by output (Nakano et al. 2009). The data of $\mathrm{CO}_{2}$ emissions by sectors is obtained from IEA $\mathrm{CO}_{2}$ Emissions from Fuel Combustion.

\section{Results}

The total $\mathrm{CO}_{2}$ emissions embodied in China's exports to the EU can be obtained from Equation 11. With the growth of China's commodity exports to $\mathrm{EU}$, the embodied $\mathrm{CO}_{2}$ emissions rose sharply, especially after 2001. Our calculations show that in 2006, approximately 532.35 Mt or $8.85 \%$ of China's $\mathrm{CO}_{2}$ emissions were caused by exports to the EU-15, increasing from 95.04 Mt or $2.99 \%$ in 1995 . By contrast, the $\mathrm{CO}_{2}$ emissions embodied in the EU's exports to China were much lower. Using Eq. (13), we found that the EU's exports to China produced emissions of 26.05 Mt in 2006, which was an increase from the 5.78 Mt generated in 1995; this accounts for only $0.17 \%$ in 1995 and $0.73 \%$ in 2006 of EU's annual emissions. The EU has a large and growing emissions deficit with China. From 1995 to 2006, the emission deficit rose from 89.26 Mt to $506.31 \mathrm{Mt}$, or from $3.07 \%$ to $8.41 \%$ of China's total $\mathrm{CO}_{2}$ emissions for those years respectively (see Figure 3).

It is essential to examine the cause of the emission imbalance of China and the EU. Since the EU-15 cannot be decomposed by country, and the emissions embodied in EU's exports are much lower than China's, using SDA, we can only decompose the changes of emissions embodied in China's exports to the EU. Figure 4 shows a decomposition of these $\mathrm{CO}_{2}$ emissions 
Figure 3: Balance of trade embodied $\mathrm{CO}_{2}$ emissions between $\mathrm{EU}$ and China (Mt)

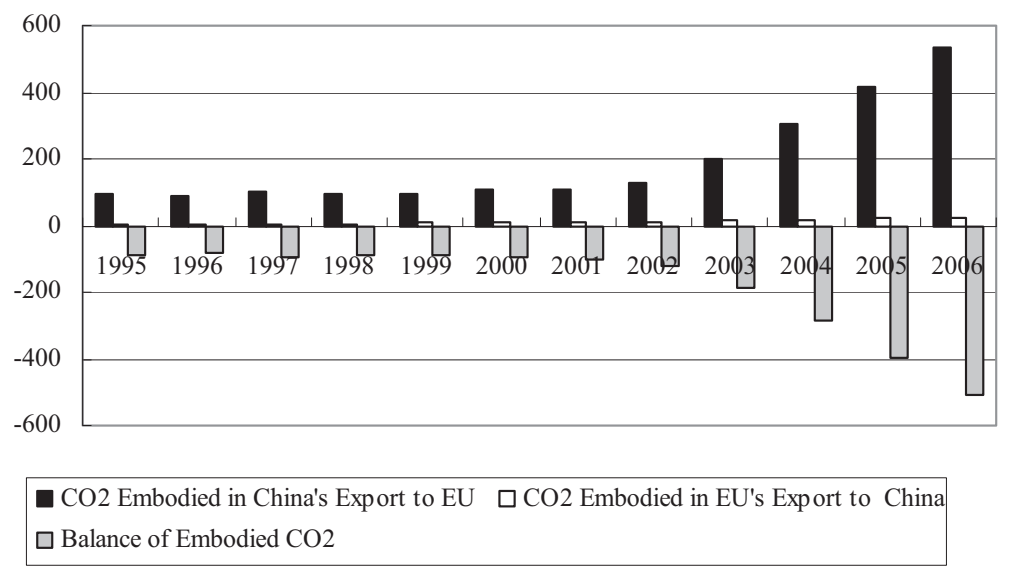

Source: Own calculations with data as mentioned in IV

from 1995 to 2006 into the three effects. During the 11 years from 1995 to 2006, the $\mathrm{CO}_{2}$ emissions embodied in China's exports to EU increased by $460 \%$. The SDA shows that the scale effect drove the increase, while the technology effect and the composition effect were somewhat offset by the former effect.. If China's technology and economic structure had remained constant, export growth (scale effect) would have caused the $\mathrm{CO}_{2}$ emissions embodied in China's export to the EU to increase by $584 \mathrm{Mt}$ (614\%) between 1995 and 2006 (instead of $460 \%$ in reality). The improved emission factors and structural changes in production technology effect) led to a $144 \mathrm{Mt}$ decrease (-151\%). The composition effect led to a $2.48 \mathrm{Mt}$ decrease $(-2.6 \%)$.

Figure 4: Decomposition of the changes of embodied $\mathrm{CO}_{2}$ emissions in China's exports to the $\mathbf{E U}$

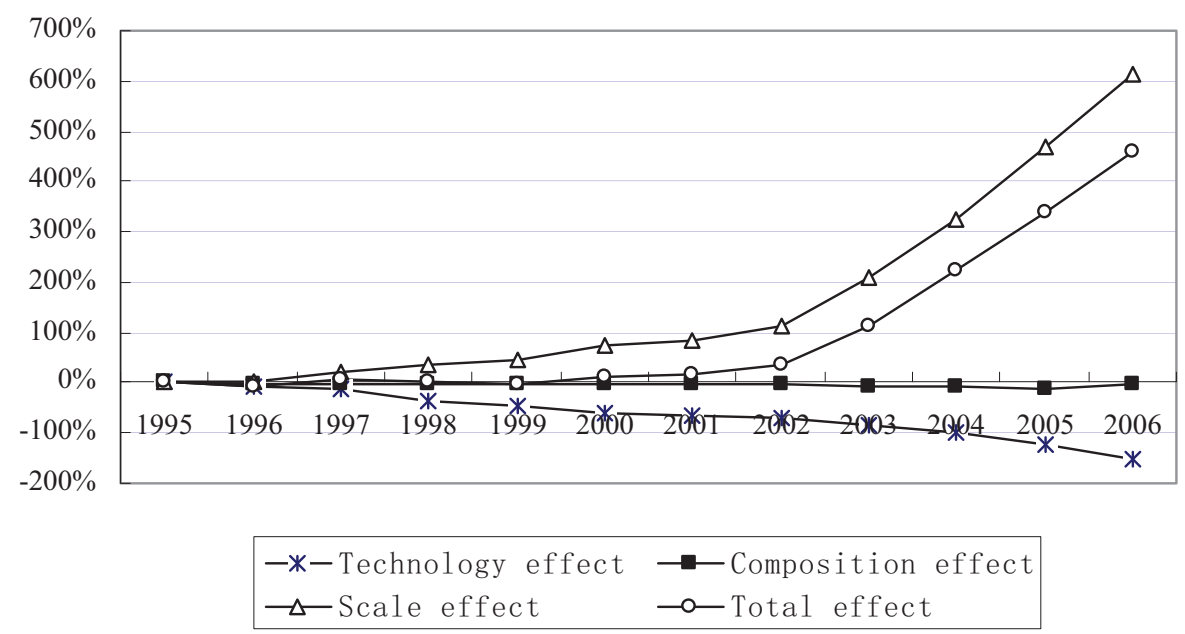

Source: Own calculations with data as mentioned in IV 
The technology effect was the main cause of the positive effects, which is verified by the improvement of the embodied $\mathrm{CO}_{2}$ emissions factors. All the sectors saw improvements in embodied emissions factors in 2005 compared to 1995 (see Table 3), which helped to offset parts of emissions embodied in China's exports to EU.

Table 3: The embodied $\mathrm{CO}_{2}$ factors by sector in China（kg/US-\$ output）

\begin{tabular}{lrrr}
\hline & 1995 & 2000 & 2005 \\
\hline 1 Agriculture, hunting, forestry and fishing & 1.58 & 1.19 & 1.26 \\
2 Mining, quarrying and petroleum refining & 5.37 & 2.91 & 3.67 \\
3 Food products, beverages and tobacco & 2.41 & 1.38 & 1.52 \\
4 Textiles, textile products, leather and footwear & 2.66 & 1.40 & 1.83 \\
5 Wood and products of wood and cork & 4.73 & 2.03 & 2.32 \\
6 Pulp, paper, paper products, printing and publishing & 4.87 & 2.64 & 2.81 \\
7 Chemicals and chemical products & 6.63 & 3.84 & 4.20 \\
8 Basic metals and other non-metallic mineral products & 8.92 & 6.08 & 7.01 \\
9 Fabricated metal products, machinery \& equipment & 4.32 & 2.51 & 2.75 \\
10 Transport equipment & 3.44 & 2.18 & 2.63 \\
11 Rubber and plastics products and other manufacturing & 4.39 & 2.87 & 3.49 \\
12 Utilities & 31.11 & 13.49 & 15.48 \\
13 Construction & 4.31 & 2.72 & 2.53 \\
14 Transport and storage & 2.15 & 1.60 & 1.86 \\
15 All other services & 2.31 & 1.40 & 1.48 \\
\hline
\end{tabular}

Source: Own calculations with data as mentioned in IV

It is useful to break down the emissions embodied in China's exports to EU by sectors to further analyze the composition effect. Figure 5 shows a breakdown of the growth in emissions by sector. In 2006, "Fabricated metal products, machinery and equipment" generated $239 \mathrm{Mt} \mathrm{CO}_{2}$ emissions, accounting for approximately $44.59 \%$ of all emissions embodied in exports to the EU. The other sectors that contributed most directly to the embodied emissions were "[b]asic metals and other non-metallic mineral products" (13.41\%), “[r]ubber, plastics products and other manufacturing" (13.27\%) and "[c]hemicals and chemical products" (11.78\%). The more contentious sector of textiles, however, accounted only for an estimated $9.42 \%$ of $\mathrm{CO}_{2}$ emissions embodied in exports to the EU. The evidence suggests that the recent growth in export-generated emissions resulted from an increase in China's export of advanced products when compared to previous years. The different composition of the major sectors of export emissions in 1995 shows this clearly: specifically, "[c]hemicals and chemical products" 
(28.36\%), “[f]abricated metal products, machinery and equipment" $(23.45 \%)$, “[t]extiles, textile products, leather and footwear" (14.51\%), “[r]ubber, plastics products and other manufacturing" (13.2\%) and "[b]asic metals and other non-metallic mineral products" (10.42\%).

Figure 5: The emissions embodied in China's exports to EU by sectors (Mt)

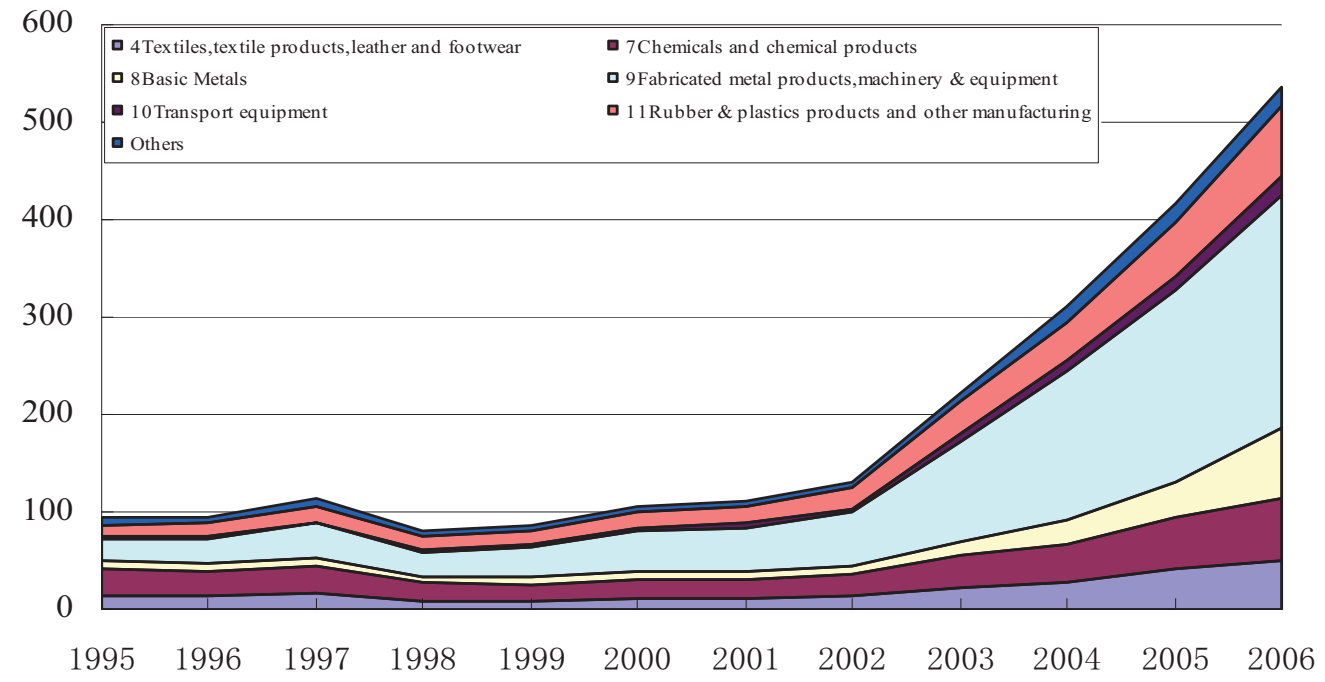

Source: Own calculations with data as mentioned in IV

\section{Conclusion and policy recommendations}

Our analysis clearly shows that there is a dangerous and ever-increasing " $\mathrm{CO}_{2}$-deficit" in the trade between the EU and China, which is considerably higher than the parallel trade deficit, calculated here as exports to imports ratio in contained CO2 and in US- $\$$ respectively ${ }^{2}$ : China's exports to EU had been 2.6fold higher (2009) than imports from the EU, and COs embodied in China's exports were 20 fold the $\mathrm{CO}_{2}$ embodied in the imports from the EU (2006). The EU has outsourced its energy-related carbon emissions by ca 13.6\% 2006/7. An improved bilateral trade balance that features increased EU exports to China would offer virtually no serious improvement in the reduction of the trade-related $\mathrm{CO}_{2}$ balance, as production in the EU generates comparatively little in terms of carbon emissions. However, the increase in China's export of $\mathrm{CO}_{2}$-intensive goods to the EU has contributed heavily to the bilateral trade deficit in recent years. Indeed, the dynamics of the $\mathrm{CO}_{2}$ trade imbalance are even more alarming than the growing trade imbalance itself. Figures 1, 3, and 4 clearly show that the China-EU trade im-

\footnotetext{
${ }^{2}$ With this argument, we do not stipulate that the ideal bilateral trade balance is equal to zero. However, an exploding bilateral trade deficit can have a macroeconomic impact.
} 
balance has grown unsustainable as well as the trade-related $\mathrm{CO}_{2}$ emissions; policy responses regarding the environmental implications are urgently needed.

With this in mind, our first policy recommendation is for the creation and implementation of a new carbon footprint accounting system between China and the EU. Once established, other countries should also be encouraged to join. Although there are still different views and practical issues on how to implement such a continual accounting system, we believe this is a move in the right direction toward a global policy prescription to stabilize greenhouse gas emissions. Through its ever-increasing imports from China, the EU has effectively outsourced a growing amount of its $\mathrm{CO}_{2}$ emissions and will continue to do so more and more. Indeed, the ecological footprint of the EU in China with respect to $\mathrm{CO}_{2}$ is large and growing. This sheds new light on the EU-27's turnaround in $\mathrm{CO}_{2}$ emissions "made in EU", which peaked in 2005 and has declined in the years since. Were its carbon footprint in China to be added - not to mention the footprints it leaves in its other trading partner countries - the EU's $\mathrm{CO}_{2}$ balance would look much less green. Not only would this result in the EU's emissions being some 13\% higher, it would also reveal China to be a little less dirty than it is commonly viewed.

However, there remains the question of whether this approach to looking at $\mathrm{CO}_{2}$ emissions is legitimate and reasonable in a globalized economy. This approach is not meant to fuel a meaningless blame-game of political rhetoric. Rather, it is meant to help inform climate change mitigation efforts by promoting greater accountability among nations and economic blocs.

The question that underlies this research is that of responsibility. Specifically, should accountability for a carbon footprint rest with the country where final consumers reside? This approach would reflect a consumer-oriented view, which places responsibility for $\mathrm{CO}_{2}$ reductions on the consumer nation. This view is in stark contrast with the traditional producer-oriented view, which underlies the polluter-pays-principle in environmental economics. In a closed economy, be it a national economy, the economy of a trading bloc or even the global economy, both views are identical given that all of what is produced is also consumed where the consumption takes place. In such a closed economy, at least in an idealized perfect economic world, environmental regulations are uniform throughout. In the real world, where very different regulations are found in different countries around the world, this is clearly not the case. As a result, false incentives are generated that lead to a large-scale misallocation of capital resulting in huge additional $\mathrm{CO}_{2}$ emissions.

When comparing the two views on emissions responsibility, the producer-oriented view seems to be the superior one. Those who physically generate emissions, cause damages and harm 
others are held responsible for their negative externalities. These externalities are internalized in the cost calculations of producers, and consumers are made to bear these additional costs. In our case, however, the consumers benefit from lower prices and the costs in the form of global warming are born by all present and future human beings. Internalization policies are typically much weaker in developing countries than in developed ones, and this is indeed the case when comparing China and the EU. Thus, the textbook wisdom of the producer-oriented view does not apply in reality without problems. If there are vast regulatory differences between developed and developing countries that cannot be eliminated in the medium term, regulatory arbitrage occurs. That is, there is a large-scale outsourcing of $\mathrm{CO}_{2}$ intensive production from OECD countries to developing countries like China. On the other hand, China benefits from the production, trade, employment and income effects of producing and exporting goods that generate large amounts of $\mathrm{CO}_{2}$. China is thus exposed to moral hazard, since greenhouse effect risks are distributed throughout the global community. Meanwhile, EU producers exploit this moral hazard by - intentionally or unintentionally - outsourcing environmentally unfriendly production to China in order to bypass domestic environmental regulations and benefit from lower import prices. This problem is further complicated by the fact that the world's cumulative $\mathrm{CO}_{2}$ balance, the sum of all production emissions since the Industrial Revolution, is clearly tilted towards OECD countries. Even more so as China can claim that the cumulated $\mathrm{CO}_{2}$ balance is clearly tilted towards the developed countries, and that China is simply trying to catch up with the level of output of the advanced countries which are the big polluters of the past 150 years. Overall, there seems to be a tacit collaboration on this type of trade. Under the cover of free trade it is de facto heavily distorted trade.

The consumer-oriented view holds that $\mathrm{CO}_{2}$ reduction commitments are the responsibility of those whose demand leads to production, regardless of where that production takes place. The major disadvantage of the consumer-based view is that the consumer country faces major problems when attempting to reduce emissions related to its imports. Measures available to the importing country are normally labeled as protectionist. Furthermore, responsibility for emissions related to exports is neglected if one follows the consumer-based view. Export-oriented countries, in this case China, would thus have incentives to lower standards (or withstand higher standards) for exports.

The consumer view enlarges the EU's responsibility for $\mathrm{CO}_{2}$ reduction efforts. This effort, though enormous, would reduce China's own responsibility only by about 8-9\% (if only the impact of China-EU trade is accounted for). To this end, the EU could either cut more $\mathrm{CO}_{2}$ emissions "at home" or import less $\mathrm{CO}_{2}$-intensive goods from China. Since marginal 
$\mathrm{CO}_{2}$-reduction costs are generally much higher in Europe than in China, this view advocates creating incentives for $\mathrm{CO}_{2}$ reduction efforts that are not cost-efficient

Regardless of whether one subscribes to the producer view or the consumer view, it is clear that true progress in combating climate change requires a system that addresses the current problem of differing regulatory standards at the international level. At first glance, a global system of tradable $\mathrm{CO}_{2}$-emission certificates seems the best way to achieve uniform environmental regulation worldwide. However, this solution does pose many questions. For example, there will no doubt be controversy as to how the initial endowments of emissions certificates should be allocated. There is also the question of whether all countries, at least all emerging economies, can or should be included. Thus, if we rule out this "first best" system for reasons of political realism, only national climate change policies remain.

In principle, we see three possible alternatives to maintaining the status quo with respect to the China-EU trade. These alternatives are as follows:

- China embarks on a strategy focused more on domestic demand than on export-led development. In this option, China follows an ambitious policy of increasing the $\mathrm{CO}_{2}$ efficiency of its production. Thus, the $\mathrm{CO}_{2}$ content of its exports falls considerably resulting in the technology and composition effects having a greater impact. To this end, China could introduce a general carbon tax on energy, though not necessarily the same as in the European market. Even without any specific trade regulations between the EU and China, the $\mathrm{CO}_{2}$ imbalance would be mitigated somewhat. However, the basic problem of regulatory differences and false incentives is likely to remain.

- China and the EU agree to continually report on the $\mathrm{CO}_{2}$ emissions resulting from exports and imports, and then use these reports to establish a bilateral agreement on trade embodied $\mathrm{CO}_{2}$ emissions. Hence, China would have to lower $\mathrm{CO}_{2}$-emissions incorporated in its exports to the EU and gradually lowering the gap in the emission standards vis à vis the EU. This would presumably make Chinese exports more costly and diminish their scale and dynamics, as well as increase costs for EU consumers. To enforce the agreed standards, the EU needs a monitoring system and the power to assign penalties. A bilateral agreement could include financial and technology transfer support from the EU, allowing China to upgrade its production standards. Of course, a bilateral agreement can lead to further trade distortions - the EU might outsource towards other countries - and can only be a first step towards global regulation.

- The EU could introduce tariffs on $\mathrm{CO}_{2}$-intensive Chinese imports, perhaps using a progressive rate, in order to tax outsourced $\mathrm{CO}_{2}$-emissions. Ideally, this should be accomplished within the 
framework of a bilateral agreement. Gros/Egenhofer (2010) argue that such carbon taxes can be made compatible with WTO law and are technically feasible. In the absence of a global emission trading system, this may be the "second best" option available. Priewe (1998, p.104 ff.) noted in an earlier work that national or EU-wide energy taxes can be supported by taxing energy-intensive imports to avoid international distortions, and that such taxes would be compatible with EU and international law. In the end, imports would be taxed with respect to $\mathrm{CO}_{2}$ to the same level as those produced domestically. Part of the revenues generated from the $\mathrm{CO}_{2} \operatorname{tax}$ or tariff that applies to Chinese imports could then be given to China to support technology upgrading. If applied, this regulation should eventually be extended to all EU trading partners. All of the proposed options are difficult, requiring major policy changes on both sides. The implementation of any of these should be done gradually, and kept in line with any future changes to the global trading system that may incorporate environmental protection. At present, no such environmental requirements exist in the trading system at all. Despite the difficulties involved in putting any of these alternatives into action, continuing business as usual is the worst option of all.

\section{References}

Ahmad N, Wyckoff A, 2003. Carbon dioxide emissions embodied in international trade of goods. OECD Science, Technology and Industry Working Paper, 15.

Antweiler, W., Copeland, B. R., Taylor, M. S. 2001. Is Free Trade Good for the Environment? American Economic Review 91, 877-908.

Chichilnisky G.,1994. North-south trade and the global environment. American Economic Review 84 (4), 851-874.

Copeland B.R., Taylor M. S.,1994. North-South trade and the environment. Quarterly Journal of Economics August, 755-787.

Copeland B.R., Taylor M. S.,1995. Trade and Transboundary Pollution. American Economic Review 85 (4), 716-737.

Dietzenbacher, E. \& Los, B. 1998. Structural decomposition techniques: sense and sensitivity, Economic Systems Research 10, 307- 323.

Gros, D., Egenhofer, Ch., 2010, “Taxing Climate and Trade - Taxing Carbon at the Border?” Centre for European Policy Studies, Brussels.

Grossman, G.M. and Krueger, A.B. 1991, "Environmental Impacts of a North American Free Trade Agreement", NBER Working Paper No. W391.

Guan, D., Hubacek, K., Weber, C.L., Peters, G.P., Reiner, D.M., 2008. The drivers of Chinese $\mathrm{CO}_{2}$ emissions from 1980 to 2030. Global Environmental Change 8,1-9.

John Kornerup Bang, Eivind Hoff and Glen Peters. 2008, EU Consumption, Global Pollution, Published by WWF-World Wide Fund For Nature. Gland, Switzerland. 
Leontief, W., Ford, D., 1972. Air pollution and the economic structure: empirical results of input-output computations. In: Brody, A., Carter, A.P. (Eds.), Input-Output Techniques. North Holland, Amsterdam, 9-30.

Li Y, Hewitt C N, 2008. The effect of trade between China and the UK on national and global carbon dioxide emissions. Energy Policy, 36(6): 1907-1914.

Nakano, S., Okamura, A., Sakurai, N., Suzuki, M,. Tojo, Y,. Yamano, N. 2009. The measurement of $\mathrm{CO}_{2}$ embodiments in international trade: Evidence from the harmonised Input-Output and bilateral trade database, OECD Science, Technology and Industry Working Paper, 3.

Peters, G. P, Weber, C.L., Guan, D., Hubacek, K.2007. China's Growing $\mathrm{CO}_{2}$ Emissions: A Race between Increasing Consumption and Efficiency Gains. Environmental Science \& Technology 9: 5939-5944.

Priewe, J., 1998: Die Öko-Steuer-Diskussion. Positionen und Kontroversen - eine Bilanz. Berlin.

Shui B., Harriss R C., 2006. The role of $\mathrm{CO}_{2}$ embodiment in U.S.-China trade. Energy Policy, 34(18): 4063-4068.

Wang, T., Watson, J., 2007. Who Owns China's Carbon Emissions? Tyndall Centre for Climate Change Research, Sussex, UK.

Weber, C. L, Peters, G. P, Guan, D, Hubacek, K.2008. The contribution of Chinese exports to climate change. Energy Policy 6:1-6.

Yan Y.F., Yang L.K. 2010. China's Foreign Trade and Climate Change: A Case Study of $\mathrm{CO}_{2}$ Emissions, Energy policy 38:350-356. 
Publisher: Competence Center "Money, Finance, Trade and Development " HTW-Berlin - Treskowallee 8, 10318 Berlin Prof. Dr. Sebastian Dullien, Prof. Dr. Jan Priewe

http://finance-and-trade.htw-berlin.de

Hochschule für Technik und Wirtschaft Berlin

University of Applied Sciences

ISSN:

$2192-7790$

(c) All rights reserved. Reproduction for educational and non- commercial purposes is permitted provided that the source is acknowledged. 